\title{
SZÍV- ÉS ÉRRENDSZERI MEGBETEGEDÉSEK KÖZÖSSÉGRE IRÁNYULÓ PREVENCIÓJA: FÓKUSZBAN A STROKE
}

\author{
Szerzők: \\ Szerdi Márta \\ Debreceni Egyetem \\ Szőllősi Gergő József \\ Debreceni Egyetem \\ Hegedűs Réka \\ Debreceni Egyetem \\ Barth Anita \\ Debreceni Egyetem
}

\author{
Lektorok: \\ Ujváriné Dr. Siket Adrienn \\ Debreceni Egyetem \\ Dr. Sárváry Attila \\ Debreceni Egyetem
}

...és további két anonim lektor

Első szerző e-mail címe:

marti199971@gmail.com

\begin{abstract}
Absztrakt
Az elvégzett kutatás arra irányult, hogy felmérjük az egészségügyi centrumoktól távol eső, Szabolcs-Szatmár-Bereg megye Újdombrád község lakóinak betegség specifikus tudását, jelen esetben a stroke-kal kapcsolatban. Ezen túlmenően megvizsgáltuk, menynyire hatékonyak a prevenciós előadások, a lakosság mennyire tartja ezeket hasznosnak, és hogy tartanak-e igényt további, más betegségekről szóló előadásoknak is.
\end{abstract}

Kulcsszavak: stroke, Újdombrád, egészségfejlesztés, prevenció

Diszciplina: egészségtudomány

\footnotetext{
Abstract

COMMUNITY-BASED PREVENTION OF CARDIOVASCULAR DISEASE: FOCUS ON STROKE

The aim of the study was to assess the disease-specific knowledge of the inhabitants of the municipality of Újdombrád in Szabolcs-Szatmár-Bereg County in this case in
} 
relation to strokes. In addition, we examined how effective the health education was, and how useful the population finds them, lastly if they want more additional lectures about other diseases.

Keywords: stroke, Újdombrád, health promotion, prevention

Disciplines: health sciences

Szerdi Márta, Szőllősi Gergő József, Hegedűs Réka és Barth Anita (2020): Szív- és érrendszeri megbetegedések közösségre irányuló prevenciója: fókuszban a stroke. OxIPO - interdiszciplináris tudományos folyóirat, 2020/3, 9-18. doi: 10.35405/OXIPO.2020.3.9

Jelen kutatást a szív- és érrendszeri megbetegedések prevenciójával kapcsolatosan végeztük, melynek fő célja a strokekal kapcsolatos ismeretek feltérképezése egy Szabolcs-Szatmár-Bereg megyei község lakóinak körében. Fontos e területen is a primer prevenció, mivel világszerte a vezető halálokok közé tartoznak a kardiovaszkuláris és cerebrovaszkuláris megbetegedések.

Az Amerikai Szív Szövetség által kiadott statisztikákban 2000 és 2010 között a stroke miatti halálozás relatív aránya 35,8\%-kal csökkent, viszont évente körülbelül 795000 ember szenved el új (610 000 ember) vagy ismétlődő (185000 ember) szélütést. A legelszomorítóbb adat, amely a laikusokat is megdöbbenti, hogy az Egyesült Államokban átlagosan 40 másodpercenként ér valakit stroke, míg 4 percenként meg is hal benne valaki (Go és tsai, 2014).
Az OECD tanulmány több országban végzett elemzést az ott élők születéskor várható átlagos élettartamáról, mely a mortalitás és morbiditás mellett megfelelő mutatószáma az egyének egészségi állapotának. Az eredmények alapján a várható élettartam az OECD által vizsgált országokban megnőtt az elmúlt néhány évtizedben, azonban a növekedés az utóbbi években lelassult. Három csoportot határoztak meg, melyből hazánk a legutolsó csoportba tartozik, ahol a születéskor várható átlagos élettartam 76 év alatt volt. Továbbá ez a tanulmány kitért a keringési rendszeri betegségek miatt bekövetkező halálozásokra is. Az OECD országokban még mindig a vezető halálokok közé tartoznak, a stroke és a szívinfarktus az a két eset, mely körülbelül minden harmadik haláleset kiváltója. Ennek ellenére a halálozási statisztikák lassan ugyan, de javuló tendenciát mutatnak a betegségcsoportra 
nézve és sok országban a születéskor várható átlagos élettartam is emelkedett (OECD, 2019).

Az ENSZ 2011-es értekezletén is kiemelt szerepet kaptak a szív- és érrendszeri megbetegedések és a stroke. Mivel e betegségek a haláloki listákon vezető helyet foglalnak el, célul tűzték ki, hogy 2025-re 25\%-kal csökkentik e betegségek miatti korai halálozást. A cél elérése érdekében különböző célkitűzéseket határoztak meg, mégpedig azt, hogy a dohányzás gyakoriságát 30\%-kal csökkentik, 25\%-os relatív csökkenést szeretnének elérni a magasvérnyomás betegség prevalenciájában, valamint csökkentenék az elhízást és a diabetes mellitus előfordulását.

A célok kitűzése mellett stratégiai javaslatokat is tettek a tagországoknak. A hipertónia csökkentését a különböző termékek sótartalmának redukálásával, valamint a sófogyasztás káros hatásainak ismertetésével kívánták elérni.

Mindemellett javasolták az egészséges étrend és a fizikai aktivitás hatásainak propagálását és hangsúlyozták a rendszeres vérnyomásmérést az egészséges egyének körében.

A diabetes mellitus és az elhízás visszaszorítását az élelmiszerek transzzsírsavtartalmának csökkentése mellett a magas transzzsírsavtartalmú táplálék árának növelésével akarták megállítani, emellett fel kívánták hívni a figyelmet a rendszeres fizikai aktivitás fontosságára (Kékes, 2018).

\section{A BETEGOKTATÁS JELENTŐ́- SÉGE A PREVENCIÓBAN}

Ahhoz, hogy az emberek megfelelő tájékoztatást és ismereteket kapjanak a megelőzésről, az egészséges életmódról, a rendeleteken, lakossági szűréseken túl fontos, hogy a primer prevenció részeként a lakosság különféle prevenciós előadások formájában, akár online módon is tájékozódhasson, információt szerezzen. Ilyen kezdeményezés a Szív Világnapja, melyet 2000 óta minden év szeptemberében megrendeznek világszerte. Ezen rendezvény- és előadássorozat a kezdetektől Magyarországon is megrendezésre kerül minden évben. Budapesten 2019-ben a résztvevőknek megadatott az a lehetőség, hogy részt vegyenek ingyenes vércukorszint-, koleszterin-, érszúkület-, vérnyomás- és testzsír mérésen, valamint SCORE meghatározáson, EKG vizsgálaton is. Ezek mellett előadásokat is tartottak, melyek az életmódváltást, az egészségesebb életmódot járták körbe. A Szív Világnapi rendezvényt fővárosunk után Nyíregyházán is minden évben megtartják, ahol, hasonlóan Budapesthez, előadásokkal és szűrésekkel népszerűsítik a kardiovaszkuláris prevenció fontosságát (Net1, Net2).

Egy Olaszországi hipertónia központban végeztek egy tanulmányt, melyben 2 csoportra osztották a résztvevőket, és a folyamatos tájékoztatás hasznosságát vizsgálták, vagyis az egyik csoport csak egy alap oktatást kapott, míg a másik rendszeres online oktatásban vett részt. 
Eredményesnek bizonyult ez a módszer (Cicolini és tsai, 2013).

Ezen rendezvények azonban leginkább a felnőtteket célozzák, de a prevencióban fontos, hogy már fiatalabb korban is ismerjék és tudják, hogy milyen következménye is lehet egy-egy káros szenvedélynek vagy egészségtelen életmódnak. Erre ad megoldást a Budapesti Orvostanhallgatók Egyesülete, ahol számos előadást szerveznek és tartanak egyetemisták középiskolás hallgatóknak, többek között a kardiovaszkuláris prevencióról is. Ezek mellett a szűrővizsgálatokra és az otthon is elvégezhető önvizsgálatra hívják fel a figyelmet (Net3).

Egyéni egészségterv készítésére létrehozott online felületen fény derülhet az egyént veszélyeztető különféle kockázati tényezőkre. Ez a weboldal az Állami Egészségügyi Ellátó Központ által fejlesztett Magyar Egészségtervező Alkalmazás, ami mindenki számára egyszerűen és ingyenesen kitölthető egészségfelmérő kérdőív. A beérkezett válaszok összesítése után kiértékeli a program, hogy az adott egyén milyen rizikótényezőkkel él együtt, majd ezek után sem engedi el a felhasználó kezét az applikáció, ugyanis javaslatokat tesz arra nézve, hogy hogyan is csökkentheti és szüntetheti meg a fennálló kockázatokat. Ezt az alkalmazást egészségügyi szakemberek bevonásával alkalmazzák, ahol a páciens egy egészségtanácsadóval együtt tölti ki és értékeli a kérdőívet. Ez a fajta tanácsadás közvetlenebb, személye- sebb, több lehetőséget ad az egyénnek, hogy kérdezzen (Net4).

Elengedhetetlen tehát, hogy rendszeressé és a lakosság minden rétegének elérhetôvé váljanak olyan oktatóanyagok, előadások, melyek felvilágosítást nyújtanak egyes betegségek tüneteiről, szövődményeiről, a primer prevenció jegyében azok megelőzéséről is.

\section{MÓDSZER}

\section{Minta}

Újdombrád lakossága, a 2015-ös adatok alapján 736 fö, melynek 51,22\%-a 18-54 év közötti, 25\%-a pedig 55 év feletti lakos. Tehát a lakosság negyede abban a korban van, ahol a legmagasabb a veszélyeztetettség a kardiovaszkuláris betegségekkel kapcsolatban, valamint több mint az emberek fele olyan életkorú, amikor a legtöbbet lehet tenni a szív- és érrendszeri megbetegedések ellen. Az egészségdélutánt plakátokkal népszerűsítettük a falu különböző pontjain elhelyezett hirdetőtáblákon, valamint az orvosi rendelőben. Az egészségdélutánon 33 lakos jelent meg. Százalékosan a teljes lakosság 4,48\%-a, mely jó aránynak számít a lakosságszámot tekintve.

\section{Eszközök}

Saját szerkesztésű kérdőívünk önkéntes és anonim volt. Kérdőívünk az alábbi kérdéscsoportokat érintette: szociodemográfiai adatok, a témával kapcsolatos 
információszerzési szokások, tudásszint felmérő teszt. A 10 kérdésből álló tudásszint felmérő teszt egyszerű és többszörös választásos kérdéseket egyaránt tartalma- zott. Válaszonként egy jó pontot lehetett szerezni, így a maximálisan elérhető pontszám 10 pont lett (1. táblázat).

\section{1. táblázat: Tudásszint felmérö teszt kérdései (forrás: a Szuerzők)}

\begin{tabular}{|rl|c|}
\hline \multicolumn{2}{|c|}{ Tudásszint felmérő teszt kérdései } & Kérdés jellege \\
\hline 1. & Mi az a stroke? & Egyszeres választás \\
\hline 2. & Mi az a TIA? & Egyszeres választás \\
\hline 3. & A felsoroltak közül melyik a stroke egyik típusa? & Egyszeres választás \\
\hline 4. & $\begin{array}{l}\text { Melyik nem képviselői a legveszélyeztetettebbek a stroke } \\
\text { szempontjából? }\end{array}$ & Egyszeres választás \\
\hline 5. & $\begin{array}{l}\text { Melyik a stroke kialakulásában szerepet játszó BEFOLYÁ- } \\
\text { SOLHATÓ kockázati tényező az alábbiak közül? }\end{array}$ & Egyszeres választás \\
\hline 6. & $\begin{array}{l}\text { Melyik a stroke kialakulásában szerepet játszó NEM BEFO- } \\
\text { LYÁSOLHATÓ kockázati tényező az alábbiak közül? }\end{array}$ & Egyszeres választás \\
\hline 7. & Örökölhető-e a stroke? & Egyszeres választás \\
\hline 8. & Mely esetben kell stroke-ra gyanakodni? & Egyszeres választás \\
\hline 9. & Melyek a stroke fenyegető tünetei? & Többszörös választás \\
\hline 10. & $\begin{array}{l}\text { Az alábbiak közül melyik állítás a döntô jelentőségú a stroke } \\
\text { kezelésében? }\end{array}$ & Egyszeres választás \\
\hline
\end{tabular}

A résztvevők a tudásszint felmérő tesztet az egészségdélután elején és végén is kitöltötték. Az előadás végén kitöltött tudásszint felmérō teszt ugyanazon kérdéseket tartalmazta, mint az első kérdőív, de más sorrendben, ezzel elkerülve, hogy valaki emlékezetből válaszoljon a kérdésekre. Az előadás végén a tudásszint felmérő teszten kívül egy elégedettségi kérdőívet is kitöltöttek a résztvevők.

\section{Eljárás}

Egy általunk szervezett egészségdélután keretén belül tartottuk második alkalommal prevenciós előadásunkat a stroke témakörében, a Szabolcs-Szatmár-Bereg megyei Újdombrád község lakóinak. Az előadás előtt és az előadás után is felmérésre került a résztvevők ismerete a témakörrel kapcsolatosan. 
Az adatok feldolgozása és elemzése a Stata Statistical Software: Release 13. for statisztikai szoftvercsomag alkalmazásával történt. Az adatok elemzése során első lépésben a folytonos változók normalitását vizsgáltuk meg (Sapphiro-Wilk próbával). Az első tudásszint felmérő teszt követte a normális eloszlást, a második azonban nem, ezért az előtte-utána típusú elemzések nem-paraméteres eljárásokkal történtek meg. Az adatpárok összehasonlítása Wilcoxon-féle előjeles rangpróba tesztekkel történt meg. Az adatok bemutatása a kérdőív kérdéseire adott válaszok százalékos megoszlásának segítségével történt meg, ahol az adott válaszhoz tartozó részarányok kerültek bemutatásra.

\section{EREDMÉNYEK}

A résztvevök szocio-demográfiai adatai

A megjelentek körében a nemek szerinti eloszlást tekintve többségben voltak a nők (nő: 78,79\% (N=26); férfi: 21,21\%-ot $(\mathrm{N}=7))$. Az életkor szerinti megoszlás bemutatásánál a KSH által alkalmazott korcsoportok szerinti felosztást alkalmaztuk. Ez alapján elmondható, hogy a résztvevők 6,06\%-a (N=2) 0-18 éves, 78,79\%a $(\mathrm{N}=26)$ 19-54 éves, $15,15 \%-\mathrm{a} \quad(\mathrm{N}=5)$ pedig 55 év feletti. A résztvevők többsége középfokú iskolai végzettséggel rendelkezik (felsőfokú: 6,06\% ( $\mathrm{N}=2)$; középfokú: $72,72 \%(\mathrm{~N}=24)$; alapfokú: 21,21\% (N=7)) (lásd 2. táblázat).

2. táblázat: Szocio-demográfiai adatok $(N=33)$. Forrás: a Szerző́k

\begin{tabular}{ll|r}
\hline \multicolumn{1}{c|}{ Változók } & \multicolumn{1}{c}{ Résztvevők } \\
\hline Átlagéletkor & Évek & \multicolumn{1}{c}{$41,67 \pm 14,32$} \\
\multirow{2}{*}{ Korcsoportok } & $0-18$ & $6,06 \%(\mathrm{~N}=2)$ \\
& $19-54$ & $78,79 \%(\mathrm{~N}=26)$ \\
\multirow{2}{*}{ Nem } & $55+$ & $15,15 \%(\mathrm{~N}=5)$ \\
& Nö & $78,79 \%(\mathrm{~N}=26)$ \\
\multirow{2}{*}{ Iskolai végzettség } & Férfi & $21,21 \%(\mathrm{~N}=7)$ \\
& Alapfokú & $21,21 \%(\mathrm{~N}=7)$ \\
& Középfokú & $72,72 \%(\mathrm{~N}=24)$ \\
& Felsőfokú & $6,06 \%(\mathrm{~N}=2)$ \\
\hline
\end{tabular}

A rész̨tvevók információkeresési sqokásai

Az 1. ábráról leolvasható, hogy a legtöbben az internetről $(48,48 \%, \mathrm{n}=16)$ szerzik információikat a betegséggel kapcsolatosan. Magas azon emberek száma is, akik orvosuktól $(24,24 \%, n=8)$ kérnek tájékoz- 
tatást, valamint azok is kiemelkednek, akik egyáltalán nem néztek utána a szélütésnek (36,36\%, n=12). Ezzel szemben elenyésző azon emberek száma, akik családjuktól
$(9,09 \%, \mathrm{n}=3)$, barátoktól $(6,06 \%, \mathrm{n}=2)$, körzeti ápolótól $(9,09 \%, \mathrm{n}=3)$, valamint egyéb helyről $(3,03 \%, n=1)$ szerzi be információit.

1. ábra: Stroke-kal kapcsolatos információszerzési források $(N=33)$. Forrás: a Szuerzőo

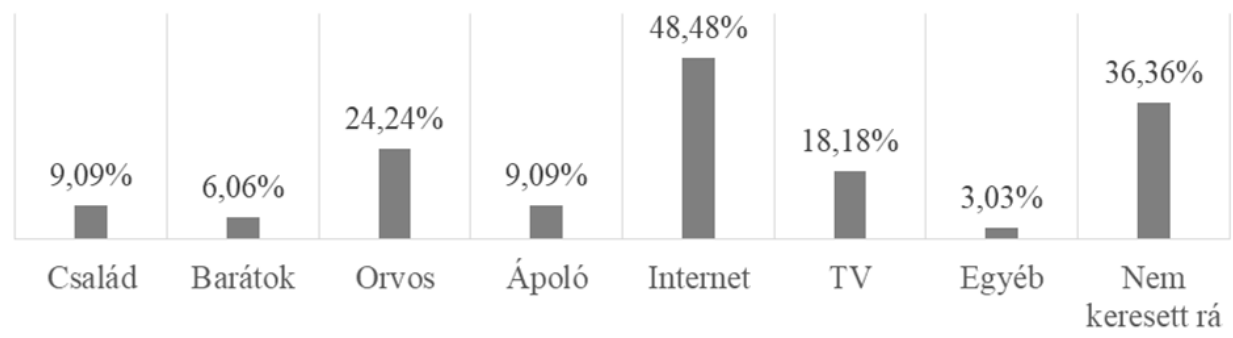

A rész̧tvevoók ismeretei

a stroke-kal kapcsolatban

A résztvevők előadás előtti tudásszint felmérő tesztjeinek az összesített pontszámainak mediánja 5,00 (iqr=2,00), míg ez a szám az előadás után kitöltött tesztek esetében 9,00 (iqr=2,00). A tudásszint változásában szignifikáns összefüggést tapasztaltunk ( $\mathrm{p}<0,001$; lásd: 2 . ábra).

2. ábra: az elöadás elötti és utáni tudáspontszám alakulása (N=33). Forrás: a Szerzók

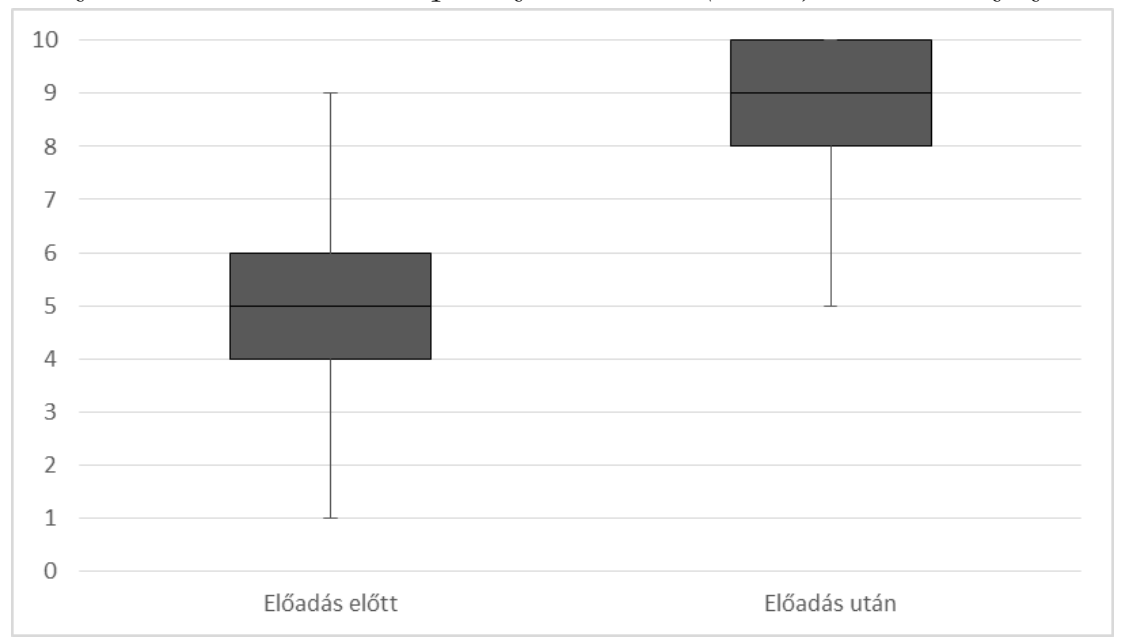


A szocio-demográfiai tényezők közül az életkor nem bizonyult befolyásoló tényezőnek (Coeff: -0,004; $\mathrm{p}=0,878$ ). A nemek vonatkozásában elmondható, hogy mind a nők mind pedig a férfiak szignifikánsan magasabb pontszámot értek el az előadás utáni tudásszint felmérő teszten $(\mathrm{p}<0,001)$. Az iskolai végzettség tekintetében elmondható, hogy csupán a középfokú iskolai végzettséggel rendelkező személyek értek el szignifikánsan magasabb pontszámot $(\mathrm{p}<0,001 ; 2$. táblázat).

2. tábláą: A tudásszint változása a szocio-demográfiai tényezőo vonatkozásában $(\mathrm{N}=33)$. Forrás: a Szerzoōk

\begin{tabular}{ll|ccc}
\hline Változó & & $\begin{array}{c}\text { Előadás elötti } \\
\text { tudáspontszám } \\
\text { medián (iqr) }\end{array}$ & $\begin{array}{c}\text { Elóadás utáni } \\
\text { tudáspontszám } \\
\text { medián (iqr) }\end{array}$ & p-érték \\
\hline Nem & Férfi & $4,00(6,00)$ & $9,00(1,00)$ & $\mathrm{p}<0,001$ \\
& Nő & $5,00(2,00)$ & $9,00(2,00)$ & $\mathrm{p}<0,001$ \\
\hline Iskolai & Alapfokú & $6,00(4,00)$ & $8,00(3,00)$ & $\mathrm{p}=0,146$ \\
végzettség & Középfokú & $5,00(2,00)$ & $9,00(1,00)$ & $\mathrm{p}<0,001$ \\
& Felsőfokú & $5,00(0,00)$ & $8,50(0,50)$ & $\mathrm{p}=0,179$ \\
\hline
\end{tabular}

A rész̨uvevók véleménye az egészségdélutánról

Az értékelő kérdőív adatainak elemzése alapján elmondható, hogy résztvevők egy 10 fokú Likert-skálán átlagosan 9,91 pontra értékelték annak hasznosságát. Valamennyi résztvevő igényt tartana további prevenciós előadások részvételére.

\section{MEGVITATÁS}

Az életkori eloszlást figyelembe véve magyarázható az, hogy a kérdőívet kitöltôk nagy része az interneten keres információkat a betegségekkel, annak megelőzésével kapcsolatosan. Laikusként azon- ban nem mindig egyszerű kiszűrni azt, hogy melyik honlap közöl hiteles információkat az olvasóval, így a prevenciós előadások tartása segítheti a világhálón is böngészőket abban, hogy felismerhessék a hamis híreket.

Abból, hogy a megjelentek nagy része önbevallása alapján már korábban tájékozódott a betegségről, az következne, hogy a tudásszint felmérő teszten magas pontszámok születnek. Ez azonban nem így alakult, hiszen az előadás előtti tudásszint felmérô teszten a megszerezhető pontok közel felét érték csupán el. Ez is alátámasztja azt a feltételezést, hogy ugyan in- 
formálódnak az egyének a betegségekről, azonban ezek az információk nem biztos, hogy hitelesek. Az információszerzési szokásokból kitűnik az is, hogy sok olyan ember van, aki egyáltalán nem néz utána a betegségnek, vagy az azzal kapcsolatos prevenciós stratégiáknak sem. Ezen hozzáállás is épp úgy veszélyes lehet, mint a hitelt nem érdemlő forrásokból való tájékozódás. Ugyanis, ha a stroke-kal kapcsolatban valaki azt az alap információt sem tudja, hogy hogyan ismerhető fel az, ha valaki szélütést szenved el, a károsult személy nem jut időben kórházba, mellyel az egészségben eltöltött életéveinek száma lecsökkenhet.

A tudásszint felmérő teszt eredményei alapján elmondható, hogy a résztvevők keveset tudtak a betegséggel kapcsolatosan. Ezen tudatlanság vezethet ahhoz, hogy a kardiovaszkuláris és cerebrovaszkuláris kórképek miatti halálozás még mindig élen jár a haláloki listán. A prevenciós előadások tartása ezt a tudatlanságból fakadó megbetegedéseket és felesleges halálokat előzhetné meg, mellyel csökkenthető lenne a betegségteher, amit az egyének kiesése a munkából és a kórházakba való bekerülése ró az egészségügyre, családokra, magára az egyénre, valamint közvetve az egész társadalomra. Ugyanakkor a prevenciós előadások végén mért tudásszintbeli javulás mutatja a prevenciós előadások hatékonyságát. A résztvevők többsége figyelmesen hallgatta végig az előadást, és összefüggéseiben is értelmezték az elhangzottakat, mely tu- dással már sikeresen ki tudták tölteni a kérdőívet.

Az elégedettségi kérdőív eredményéből következik, hogy az emberek szívesen vettek részt a prevenciós előadáson, hasznosnak gondolták azt. A személyes beszélgetésekből is tükröződött, hogy az emberek további előadásokat is szeretnének meghallgatni különféle egészséggel kapcsolatos témákban.

\section{KORLÁTOZÁSOK}

Az előadáson kis létszámban jelentek meg, így a minta nem reprezentatív. A nem, életkor, iskolai végzettség szerinti eloszlás sem egyenlő, mely így az esetleges tudásszintbeli változás összehasonlítása során sem mutat valós képet.

\section{KONKLÚZIÓK}

Összességében elmondható, hogy a lakosság számára tartott egészséggel kapcsolatos, prevenciós jellegű előadások hasznosak. Ezt tükrözik egyrészt a tudásszint felmérő teszten kapott eredmények valamit az értékelő kérdőív eredményei is. A résztvevők egy-egy ilyen előadás alkalmával hasznos, a mindennapokban is használható információt nyernek különféle betegségcsoportokkal kapcsolatosan. Mindemellett hozzásegíti őket az interneten található információk hitelességének megállapításához is. A község lakóinak számára tartott előadások számának növelése éppen ezért indokolt. A létszám nö- 
velése mellett fontos lenne azon egyének megnyerése is, jelen esetben az idősebbek és a férfiak, akik jelen egészségdélutánon alacsony számban vettek részt, hisz vannak olyan betegségek, amelyek kifejezetten rájuk jelentenek veszélyt.

\section{IRODALOM}

Go, A. S. et al. (2014): Executive Summary: Heart Disease and Stroke Statistics-2014 Update. Circulation, 129, 399-410. doi: 10.1161/01.cir.0000442015.53336.12 OECD (2019), Health at a Glance 2019: OECD Indicators, Paris: OECD Publishing. doi: 10.1787/4dd50c09-en

Kékes E. (2018): A korai kardiovaszkuláris mortalitás csökkentésének ENSZ terve 2025-ig, és a program sikerének becslése. Interdiszciplináris Magyar Egészségügy, XVII. évfolyam, 7. 34-41.

Net1: Sziviunk napja-a Sziv Világnapja. Letöltés: 2020.03.30. Web: http://www. szivunknapja.hu/
Net2: Egészségügyi sұürések, elöadások, szinpadi programok - Szív Világnapja Nyíregyházán. Letöltés: 2020.03.30. Web: https://www.nyiregyhaza.hu/post/eg eszsegugyi-szuresek-eloadasokszinpadi-programok-sziv-vilagnapjanyiregyhazan-2019-09-30

Net3: Kardiovaszkuláris és tumorprevenció. Letöltés: 2020.03.30. Web: http:// semmelweis.hu/boe/prevencio/kardio vaszkularis-es-tumorprevencio/

Cicolini, G.; Simonetti, V.; Comparcini, D.; Celiberti, I.; Di Nicolad, M.; Capasso, L.M.; Flacco, M.E.; Bucci, M.; Mezzetti, A. \& Manzoli, L. (2013): Efficacy of a nurse-led email reminder program for cardiovascular prevention risk reduction in hypertensive patients: A randomized controlled trial. International Journal of Nursing Studies, 51(6), 833-843. doi: 10.1016/j.ijnurstu.2013. 10. 010

Net4: Magyar Egészségtervezoo" Alkalmazás. Látogatva: 2020.03.30. Web: https:// egterv.aeek.hu/ 